\title{
A special issue to celebrate the 20th Anniversary of the French Association of Mechanics (A.F.M.)
}

This special edition of your Mechanics and Industry Journal is to celebrate the 20th anniversary of the Association Francaise de Mecanique (AFM).

Our association which is in fact much older given its members (Association Universitaire en Mecanique, Haut Comite Mecanique, Societe Francaise de Tribologie and so on) has since its creation sought to defend and disseminate the subject "Mecaniscience" first of all in France but also around the world by bringing together knowledge and know-how in the academic world and the industrial world.

The papers of this special issue come exceptionally from French institutions contrary to usual practice and the reality of regular editions of the magazine. I hope our foreign friends will forgive us: future issues will rectify this.

This editorial choice seeks to give special attention to, as well as to highlight, the joint projects in public university research laboratories all the while maintaining a strong link to industrial and institutional partners. It is to be noted that on this occasion the editorial line of M\&I is to provide a tribune for projects which combine a fundamental approach (theoretical, experimental, numerical) as well as an application (innovative, technical). The usual schema of partenarial collaborations in France is the CIFRE Contracts (which exist with other countries: Morocco, Brazil) but also those carried out in Joint Ventures CNRS/Industry (SAFRAN, SAINT GOBAIN, etc.), public Research organizations (CEA, ONERA, etc.), Technological Centers (CETIM, etc.) or in relation with the new IRT's (Technological Research Institutes).

The articles presented in this issue are a follow-up to a specific call-for-papers completed by a selection of papers presented during the last French Mechanics Congress (CFM) in Brest in August 2019: they have all nevertheless been subject to a "standard", complete, review. Many other articles would have merited to be included in this special issue, given their quality as well as their academic-industrial nature.

We encourage all of the national community, as well as the international one of course, to become regular readers of the Review. More particularly, we encourage then to submit their research work that corresponds to the Mechanics and Industry editorial line which is a unique complement to other more specialized or more theoretical reviews for the publication of quality papers in Applied Mechanics. 